\title{
A Literature Review of Financial Contracting Theory from the Islamic and Conventional Overviews: Contributions, Gaps, and Perspectives
}

\author{
Hechem Ajmi*, Salina Kassim** \\ *PhD Scholar, ${ }^{* *}$ Associate Professor, IIUM Institute of Islamic Banking and Finance \\ International Islamic University Malaysia
}

Hassanuddeen Abdul Aziz

Professor, Kulliyyah of Economics and Management Sciences

International Islamic University Malaysia

\author{
Walid Mansour \\ Advisor, Financial Sector Development Department, Saudi Arabian Monetary Authority
}

\begin{abstract}
This paper discusses the financial contracting theory from the conventional and Islamic perspectives. It provides an overview of the contributions in this field and discusses the gaps in the literature. In addition, it proposes two relevant approaches namely the financial contracting enforceability approach and the adverse selection analysis in order to deal with conflicts of interest among economic agents. The first approach is meant to assess the contract that maximizes the value of the firm subject to the enforcement constraint for the agent and the participation constraint for the principal. The second approach considers an adverse selection framework in order to determine the principal's subjective perception of the risk of default when equity and debt financings are used. Similarly, it suggests avenues for future research. Firstly, it calls for a deeper understanding of venture capital as a potential model of mushārakah. Secondly, it puts stress on the importance of examining crowd-funding functioning from the principal-agent point of view. Thirdly, it sheds some light on the necessity to yield financial explanation about the excessive use of murābahah instead of ijārah. In a nutshell, we assume that the alternative approaches can be adopted to provide relevant insights regarding the proposed future researches.
\end{abstract}

Keywords: Conflicts of interest, Optimal contract, Adverse selection, Equity-based contracts, Debt-based contracts.

JEL Classification: G32, G33, G23, G24

KAUJIE Classification: Q1, L3, T3 


\section{Introduction}

The selection of the appropriate financing tool remains a crucial decision for the principal and the agent equally when asymmetric information problems occur. Although this issue comes from the gap between the declared and non-declared benefits generated by the firm, the agents become unable to align their interests and handle bankruptcy. In order to mitigate this problem among agents, the conventional theory provides several explanations and insights throughout the theory of the firm, the agency theory, and the incomplete contract theory. The incomplete contract theory came out with significant evidences regarding conflicts of interest among agents. However, it has been widely criticized for several reasons that will be discussed in this paper with the aim to find out an alternative solution.

From the Islamic perspective, several papers have dealt with financing contracts, in particular, profitand loss sharing (PLS) financial agreements versus conventional debt. For instance, al-Suwailem (2005) and Nabi (2012) have shown that PLS contracts dominate standard debt in terms of cost and benefit for the contracting firm. However, it has been noticed that further insights must be highlighted regarding the PLS financial agreements and debt-like instruments in order to determine the contract that aligns agents' interests and avoids bankruptcy. Especially, as alSuwailem (1998) suggested that venture capital might be a potential model of mushārakah. Admitting that Islamic financing contract has been treated from the Sharīah perspective, further research needs to be undertaken in order to analyze the financial structure of Islamic contracts in the presence of moral hazard and information asymmetry.

This paper reviews the most relevant literature dealing with financial contracting in order to highlight their main contributions and gaps from the conventional and Islamic perspectives. This article also provides alternative approaches, namely the financial contracting enforceability approach and the adverse selection analysis. These approaches can be adopted to provide relevant insights regarding the principalagent problem, while they take into account conflicts of interest among agents and the adverse selection problem. Furthermore, we shed light on some important issues which can form the basis for future researches in this field by putting stress on the importance of venture capital and crowd funding within the economy. Similarly, we highlight the necessity to provide financial explanation for the excessive use of murābahah instead of ijārah by Islamic financial institutions.

The rest of this paper is organized as follows. The second section broadly discusses the partnership contract formation. Section three provides the literature review and highlights the gaps linked to the conventional studies. The fourth section puts stress on the most important contributions in Islamic finance and the gaps related to Islamic financing contracts. Section five discusses the alternative approaches in order to deal with Islamic financial contracting issues. The sixth section highlights the perspectives of the financial contracting theory. Finally, section seven concludes the paper.

\section{Partnership Contract Formation}

Profit-and Loss Sharing (PLS) is one of the main financing instruments in Islamic finance literature (Khaled \& Khandker, 2015, p. 76). Therefore, several studies discussed the structure of Islamic equity contracts and the profit-sharing mechanism from the principal-agent point of view in order to highlight the significance of PLS arrangement within the economic system (see Hasan, 1985; Khaled \& Khandker, 2015; Mansour, Ben Abdelhamid, \& Heshmati, 2015; Siddiqi, 1988; Khan \& Mirakhor, 1987; Mirakhor, 1987). When the agent is not seeking hundred percent bank financing of the project, he can consider a partnership contract by contributing some of his own equity capital. In this case, the principal and the agent become involved in a profit and loss sharing agreement, which is in conformity with the Islamic principles of risk and reward sharing. The profits are shared based on pre-determined rates, whereas the losses are borne in proportion to each partner's (agent's) participation. In this case, the literature mentions two types of opinions among the jurists about the profit and loss sharing process.

For instance, Hasan (1985, p. 14) discussed that the Hanafìs, the Hanbalīs and a few of the Shāfi ${ }^{\prime} \overline{1}$ scholars assumed that suppliers of capital have to bear losses in proportion to their contribution. 
However, they are free to negotiate the profit-sharing ratios. In the same way, the Mālikīs and most of the Shāfi 'is indicated that in mushärakah, the profits and losses must be shared according to the same ratio. If the principal and the agent provide the same contribution, they are supposed to have the same profit share. Nevertheless, in practice, this profit share is not identical because the principal brings only funds, whereas the agent provides his managerial skills and expertise as well as a share of the capital. Admitting that profit is the result of the combined effort of capital and expertise, keeping the profit-and loss sharing ratios equal for the principal would be unfair to the agent. It will discriminate in favor of the dormant supplier of funds (Hasan, 1985, p. 15). Based on the aforementioned evidences, the simplest structure of PLS arrangement is shown in Figure 1.

\section{Figure (1) Partnership Contract's Structure}

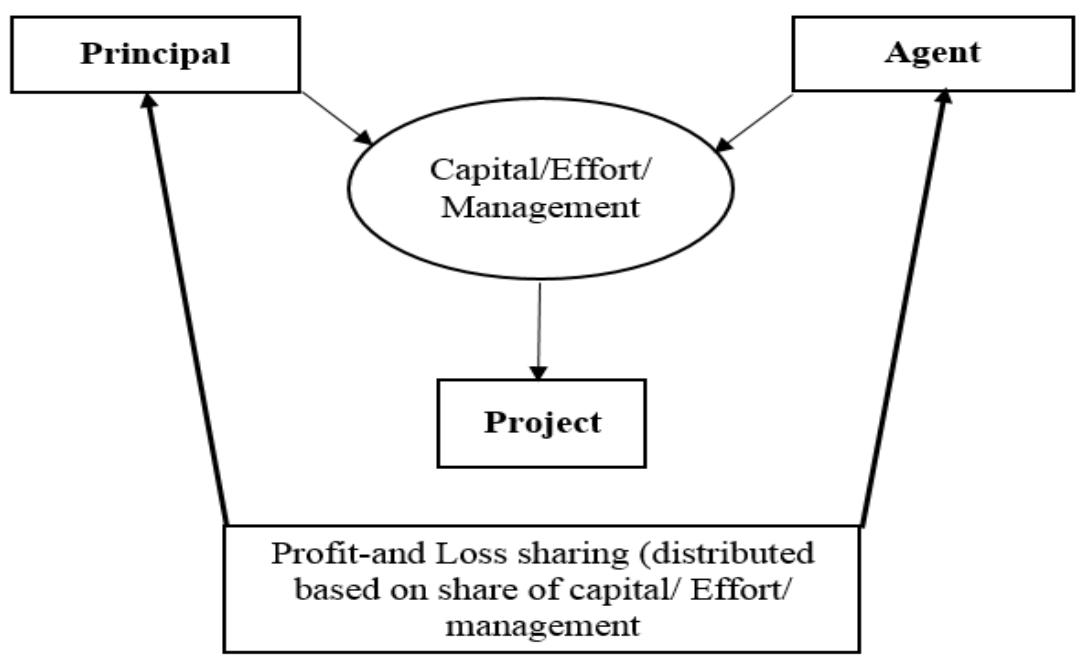

Source: Prepared by Authors.

Like traditional banks, Islamic banks providing equity financing also face credit risk. In case of profitsharing contracts, the credit risk is linked to the nonpayment of the bank's share by the agent. As stated by Khaled and Khandker (2015), "PLS financing was supposed to take care of cases where there is an identifiable flow of future profit streams from the project" (p. 77). Therefore, conflict of interest among agents may arise due to asymmetric information problem and moral hazard in the contractual arrangement (see Tag el-Din, 1991, for the examination of risk aversion and moral hazard in Islamic finance). Indeed, this problem occurs when the entrepreneur may have relevant inside information about the project and its profitability which the financier does not have access to. The lack of transparency, therefore, may induce the principal and the agent to hide relevant information about the project to satisfy their interests. From the banking perspective, equity financing may minimize the adverse selection and moral hazard problems, because there is much more disclosure of a company's books and investments (Siddiqui, 2008, p. 685 ). From the principal-agent perspective, however, the agency problems may still occur due to asymmetric information and costly monitoring (Sarker, 1999, p. 20). In line with the aforementioned evidences, in the following sections we examine the financial contracting from the conventional and the Islamic perspectives with the aim to explain the principal-agent problem when moral hazard and information asymmetry occur.

\section{Financial Contracting Theory from the Con- ventional Perspective}

The principal-agent problem has been widely examined in the conventional literature, starting from Smith (1776) who discussed some incentive issues linked to sharecropping contracts (which are profitand-loss sharing), the monitoring process, and adverse selection in human cooperation. To deal with 
these issues, Coase (1937) came up with a new theory to assess the performance of the firm by putting stress on the role of technology and return to scale, as important determinants of the size of the firm and the optimal production. However, he considered the firm as a black box and completely ignored incentive problems within it. To this extent, Hart $(1995$, p. 17 $\& 20$ ) indicated that the theory of the firm has nothing to say about the internal organization of firms. Coase's theory was later extended by Williamson (1979) as well as by Jensen and Meckling (1976) and became known as the economics of organization. These two studies established the agency theory by considering the effect of the manager and the selfish behavior of agents to assess the contractual relationship in imperfect markets. According to Williamson $(1979$, p. 234), opportunism and selfish behavior of agents constitute the key of agency theory. Nevertheless, these studies did not say much about the internal organization of the firm.

An alternative approach to address the issues in incomplete contracts proposed that the cornerstone of the incomplete contract theory is the allocation of decision rights (Hart, 1995; Hart, 1989; Hart, 2017). This theory has been extended to include the roles of bargaining power and aligns the interests of agents. Among others, Hart and Moore (1994) considered that careful allocation of decision rights can substitute for contractually specified rewards. More precisely, a bargaining power for negotiation and renegotiation of such contracts is highly critical to enable the agents' interests to be aligned. Thus, this mechanism may resolve the incentive issues relating to the principalagent problem such as the control rights and decisions.

The incomplete contract theory has been extended to cover the most important issues about the relationship between economic agents. For instance, Hart (2003, p. 74) discussed some recent theoretical thinking regarding public and private firms in an advanced capitalist economy. He made some general remarks about the relationship between the theoreticcal literature on privatization and incomplete contracting theories of the firm. Then, he adopted some insights from this literature to develop a preliminary framework of public-private partnership. Interestingly, the author found that the public-private partnership seems to be more attractive for the services sector than the construction sector. In addition, it has been shown that public-private partnership is efficient for economic agents if there are relevant performance measures, which can be adopted to reward or penalize the service provider. Similarly, Halonen-Akatwijuka and Hart (2015, p. 1) adopted some ideas from the incomplete contract theory to show that a continuing contract can reduce negotiation and renegotiation costs linked to a shortterm or long-term contract when there is uncertainty about future gains from trade.

The incomplete contract theory has been developed based on several hypotheses assuming three important conditions: (i) The principal is risk-neutral, (ii) There is only one principal and one agent; and (iii) The agents have symmetric information ex-ante. Nevertheless, relevant studies in the field have criticized the second and the third conditions (for the theoretical examination of information asymmetry and adverse selection issues in contractual arrangement, see, Ross, 1973; Arrow, 1971; Akerlof 1970). More precisely, the literature showed that moral hazard and information asymmetry constitute serious issues for financial contracting from the principalagent point of view. Consequently, the limitations of this approach are discussed in the next paragraph.

\subsection{Limitations of the Incomplete Contracting Theory}

The incomplete contract theory has brought relevant solutions for decisions and rights control for partnership agreements using the bargaining power for negotiation and renegotiation. However, the assumption related to risk neutrality constitutes a relevant issue in this regard when it comes to financiers with different risk expectations, particularly in the case of intermediated funds, as we cannot simply assume that bankers are risk-neutral. In addition, the assumption that agents do not face asymmetric information problem ex-ante is a rather strong assumption to make. In line with our statement, Ross (1973, p. 134) implies that contractual arrangements contain important elements of agency linked to asymmetric information and moral hazard. This issue has been discussed in the study of Arrow (1971) by examining the theory of risk bearing in the presence of moral hazard and information asymmetry, providing significant contributions to the contemporary analysis in the economics of uncertainty. Similarly, Jensen and Meckling 
(1976), Akerlof (1970), and Tirole (1999), showed that asymmetric information ex-ante has a significant effect on the investment decision and contract arrangement in particular. Based on these critics, this paper proposes two alternative approaches to deal with partnership arrangement in imperfect markets namely, the financial contracting enforceability approach and the adverse selection analysis (see section 5).

\section{Financial Contracting Theory from the Islamic Perspective}

Financial contracting theory has also been explored widely from the Islamic perspective, with particular focus on the notion of profit-loss and risk sharing. Furthermore, several studies dealt with moral hazard and asymmetric information problems in order to determine the optimal contracts and incentive system compatible with the Islamic contracts. In contractual arrangements conflicts of interest among agents occur when the agent hides relevant information about the project to satisfy his interest. This conflict of interest is mostly attributed to the gap between the declared and non-declared benefit generated by the firm, which can also be explained by moral hazard and information asymmetry. In order to avoid this issue, the principal may consider an incentive package. This package can be presented as a reward/punishment rules (Ahmed, 2002; Gale \& Hellwing, 1985). For instance, the principal may incorporate a bonus system in case of extra profit in order to avoid the selfish behavior of the agent. Similarly, a punishment rule can be adopted to encourage the agent to disclose relevant information about the project and, in particular, the profit generated. The existing literature in Islamic financial contracting is divided into two mainstreams. The first one justifies the marginalization of PLS agreements. The second one encourages the adoption of PLS agreements. For instance, Figure 2 highlights the percentage of Islamic financing contracts used in the economy among seventeen countries in 2012, namely Afghanistan, Bahrain, Bangladesh, Brunei Darussalam, Egypt, Indonesia, Iran, Jordan, Kuwait, Malaysia, Nigeria, Oman, Pakistan, Saudi Arabia, Sudan, Turkey, and the United Arab Emirates.

Figure (2) Financing by type of Sharī'ah-compliant contract (2012)

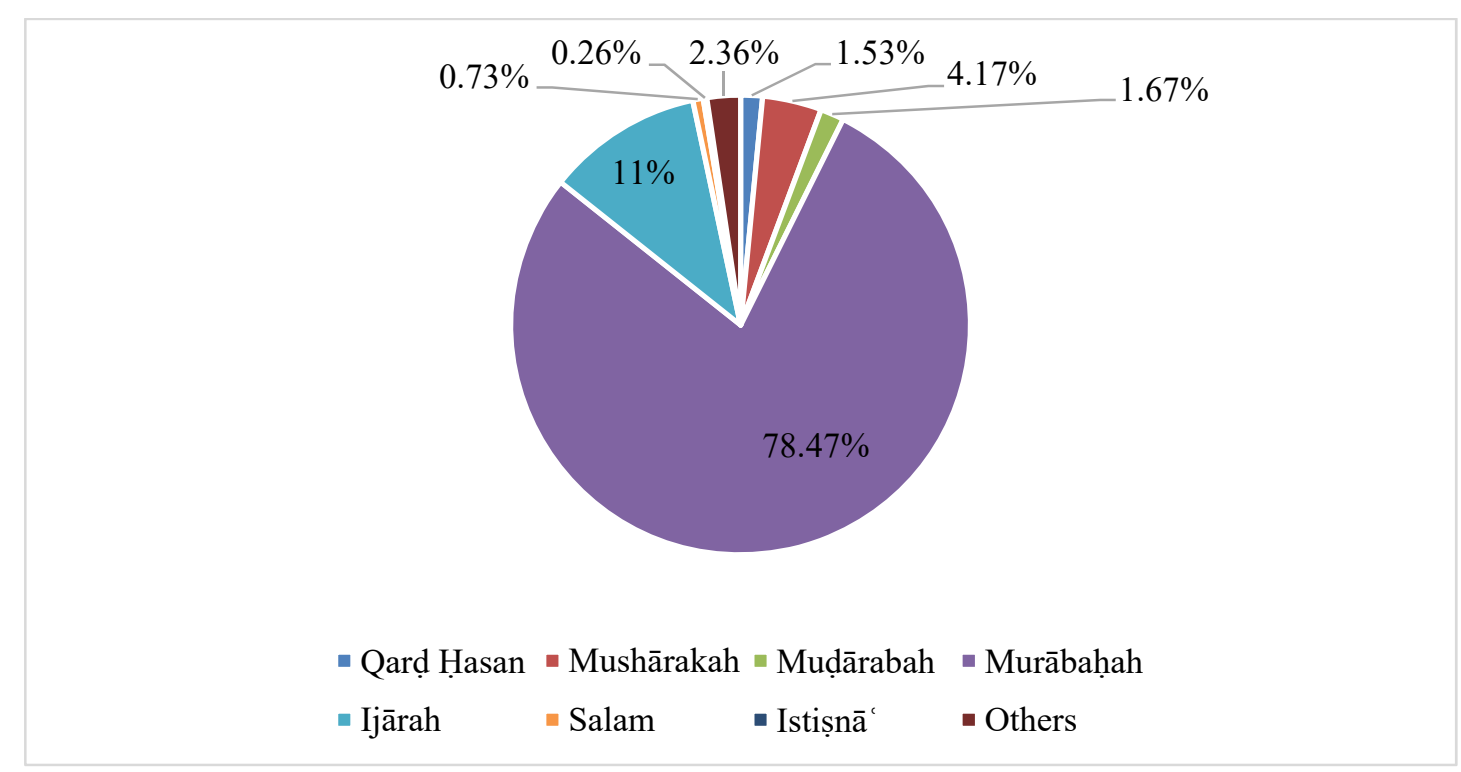

Source: (World Bank \& Islamic Development Bank Group, 2016, p. 69). 
Figure 2 clearly illustrates that Islamic banks have tended to position themselves close to conventional banks through products, such as murābahah, and ijärah, which is not in line with the theoretical underpinnings of Islamic economics. Figure 2 shows that more than 75 percent of the financing offered by Islamic banks globally is in the form of muräbahah. The ijärah contract comes second, with about 11 percent. The shares of profit-sharing contracts (mushārakah and mud̄ārabah) remain at a lowly 4.17 percent and 1.67 percent, respectively. To put it another way, it appears that less than 6 percent of global
Islamic financing is on a profit-sharing basis. The qard hasan contract stands at 1.53 percent. Overall, it is noticeable that PLS contracts represented less than 8 percent of the total of Islamic financing globally in 2012, according to the Global report on Islamic finance, 2016 (World Bank \& Islamic Development Bank Group, 2016). Considered as one of the main actors in Islamic finance, IFSB announced that adoption of equity financing experienced a slight increase in 2018, whereas the use of muräbahah decreased from 2012 to 2018 as shown in Figure 3.

Figure (3) Financing by type of Sharī ah-compliant contract (2018)

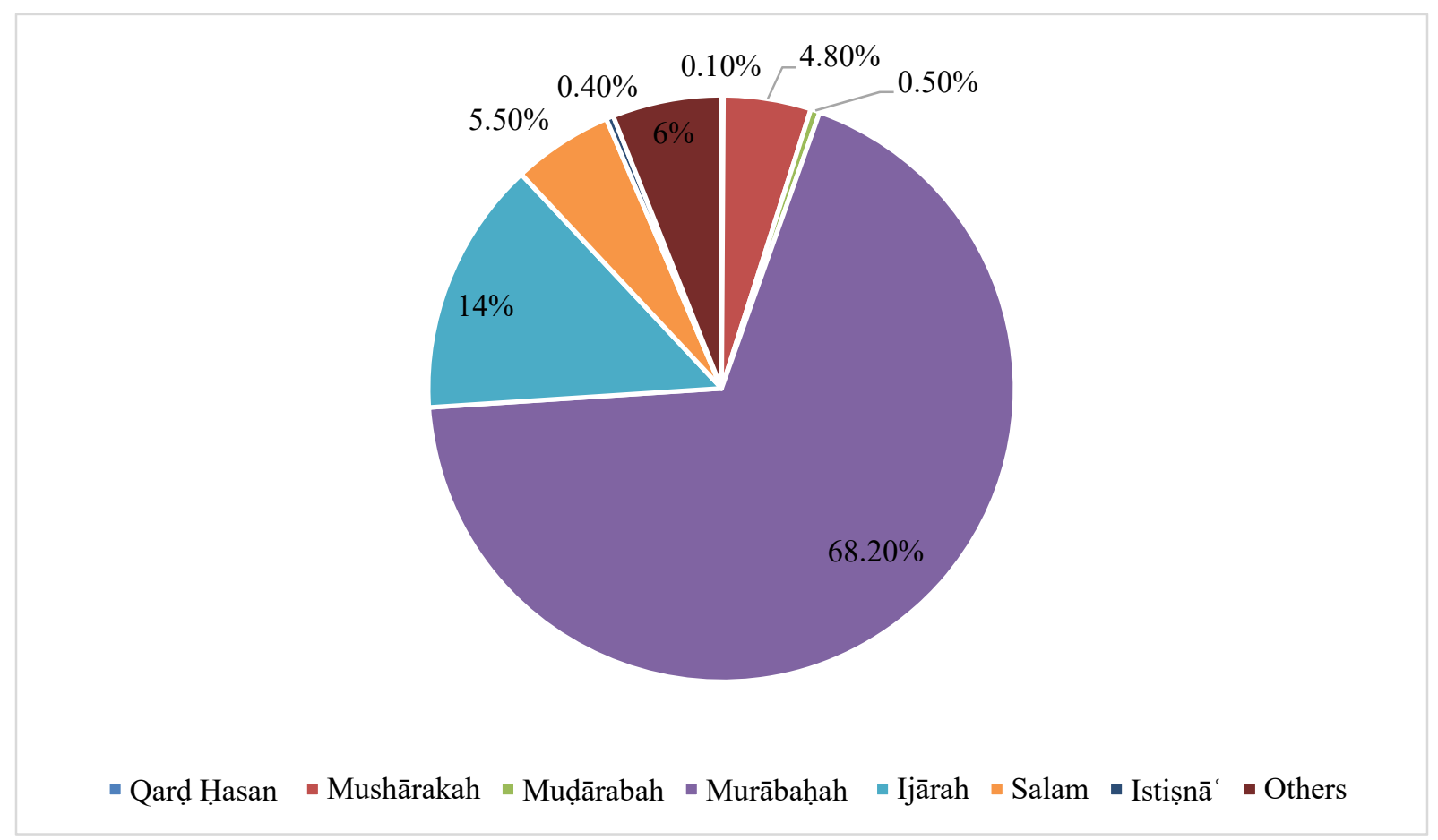

Source: https://www.ifsb.org/psifi_02.php

Figure 3 is calculated based on IFSB financial statistics of Islamic contracts used in the economy among fourteen countries in 2018, namely Afghanistan, Bangladesh, Indonesia, Iran, Jordan, Kuwait, Malaysia, Nigeria, Oman, Pakistan, Saudi Arabia, Sudan, Turkey, and the United Arab Emirates. Bahrain, Brunei Darussalam, and Egypt were not considered due to the lack of data. Figure 3 shows that murābahah represents around 68 percent of the financing provided by Islamic banks. The ijārah contract is 14 percent, whereas mushärakah and mud̄ärabah represent 4.8 percent and 0.5 percent, respectively. Comparing figures 2 and 3 , the percentage of using mushārakah increased from 4.17 percent in 2012 to 4.8 percent in 2018 , whereas the percentage of adopting murābahah decreased from 75 percent to 68.2 percent. Admitting that equitybased contracts have been marginalized by most Muslim countries, it was noticed that Pakistan has more preference for using PLS financing rather than debt financing as shown in Table 1. 
Table (1) Financing by type of Sharī' ah-compliant contract in Pakistan (2017-2018)

\begin{tabular}{|c|c|c|c|}
\hline Type of Contract & March-2017 & December-2017 & March-2018 \\
\hline Murābahah & 16.4 & 13.2 & 13.1 \\
\hline Ijārah & 6.4 & 6.4 & 6.4 \\
\hline Mushārakah & 16.3 & 22.0 & 21.2 \\
\hline Diminishing Mushārakah & 32.3 & 30.7 & 32.4 \\
\hline Salam & 5.2 & 2.8 & 2.5 \\
\hline Istișna $\bar{a}^{c}$ & 8.9 & 8.2 & 7.7 \\
\hline Others & 14.5 & 16.7 & 16.7 \\
\hline
\end{tabular}

Source: State Bank of Pakistan, Islamic Banking Department (2018, p. 4).

Table 1 shows that, in Pakistan, the percentage of using murābahah decreased from 16.4 percent to 13.1 percent between March 2017 and March 2018, whereas the percentage of ijārah remains around 6.4 percent in this period. The adoption of salam and istișn $\bar{a}$ ' also experienced a slight decrease by reaching 2.5 percent and 7.7 percent in 2018 compared to 5.2 percent and 8.9 percent in March 2017 respectively. In contrast, PLS contracts registered a significant growth between March 2017 and March 2018. In particular, mushārakah financing continued its growing trend and reached 21.2 percent in March 2018, compared to 16.3 percent in March 2017. Similarly, diminishing mushārakah recorded a slight growth in March 2018 by reaching 32.4 percent compared to 32.3 percent in March 2017. Admitting that Islamic jurisprudence encourages bankers to adopt equity financing, the success story of Pakistan may motivate scholars and practitioners to re-think about profit-and loss sharing agreements.

Among those who justified the marginalization of PLS contracts, Dar and Presley (2000), Farooq (2007), and Ebrahim and Sheikh (2016) assumed that an imbalance between management and control rights is attributed as a major cause for the lack of PLS in the practice of Islamic finance. Therefore, Dar and Presley (2000, p. 3) considered that PLS contracts require well-defined property rights to function efficiently, which is hard to satisfy especially in Muslim countries. Given this imbalance, the agency problem becomes more severe, which renders the PLS principle less attractive vis-à-vis other modes of financing. In summary, it is clear that the marginalization of musharakah is the result of external elements such as moral hazard and information asymmetry, which is in line with the study of Lone and Quadir (2017, p. 91).
To this extent, al-Suwailem (1998, p. 16) proposed venture capital as a potential model of mushārakah. More precisely, the author highlighted the main theoretical and empirical aspects of venture capital. He showed that venture capital may allow economic agents to minimize agency costs and to promote growth and development. From the Islamic perspective, the venture capital contract is much similar to the 'inān type of mushärakah. Thus, it can be an incentive to Islamic financial institutions to invest their funds and promote PLS arrangement.

Besides the financing role, the venture capitalist may provide monitoring and advice because some entrepreneurs lack the required experience in management, marketing, and financial planning. In this context, Warne (1988, p. 81) stated that if assistance cannot be acquired separately through a competitive market and in presence of asymmetric information, entrepreneurs would be willing to pay more for venture capital than for a loan without assistance. This evidence implies that the entrepreneur may accept this contract in order to benefit from the advantages of the venture capital contract, in exchange for an additional profit share for the venture capitalist. However, the study of al-Suwailem (1998) did not provide relevant evidences about the relationship between the venture capitalist model and the Islamic model in case of imperfect markets. To this extent, additional proof is needed in order to draw relevant insights about the selection of the optimal contract among venture capital and mushārakah in case of imperfect markets.

Among those who encouraged the adoption of PLS agreement, Muda and Ismail (2010, p. 262) and Sapuan (2016, p. 350) put stress on PLS financings and value creation in Islamic banks. Their studies analyzed and presented the optimal conditions of 
PLS modes to minimize the problem of asymmetric information and transaction costs. Results showed that, mudārabah remains less preferable compared to Islamic debt financing instruments such as murābahah due to the existence of asymmetric information and moral hazard (Sapuan, 2016, p. 355).

Three propositions were presented to achieve the optimal conditions of PLS contracts in Islamic finance. First, for the mudārabah contract, Islamic banks as the rabb al-māl (capital provider) must give incentives to entrepreneurs if a positive value of Islamic bank's expected net profit is obtained. Second, if the Islamic bank as the mudārib (investment manager) is also appointed as the wakil (agent), a cost of processing information is imposed upon the depositors to the mudārabah investment account. Third, for the musharakah contract, the Islamic bank is proposed to consider imposing monitoring cost (Muda \& Ismail, 2010, pp. 275-276).

Similarly, Maghrebi and Mirakhor (2015, p. 85) considered risk sharing as an effective method of economic growth and development compared to risk transfer that currently dominates financial systems. This evidence implies that risk sharing is more conducive to a socially inclusive financial system and the development of the economic system.

Ernawati (2016, p. 101) analyzed the risk of PLS financing in Indonesian Islamic banking using data obtained from the central bank of Indonesia between the years 2009 and 2014. The main purpose of the study was to measure financing risk by risk return and opportunity cost in case of PLS contracts. The results showed that risk return in mudārabah financing is more volatile than that in musharakah as it is potentially driven by the agency problem. Even though, it is found that in all groups of banks, higher returns are more promising in mudārabah than musharakah, whereas individually mushärakah is more attractive to Islamic rural bank groups. Therefore, the findings indicated that it would be more secure for Islamic banks to allocate funds in mushārakah contract, which is an alternative to muräbahah (see Majdoub \& Mansour, 2014; Majdoub, Mansour, \& Jouini, 2016; Majdoub, Mansour, \& Arrak, 2018; and Bedoui \& Mansour, 2015, for the understandings of the theoretical foundations of equity-based contracts).
Based on the agency issues related to equitybased contracts, Mansour et al. (2015, p. 21) proposed a new equity-based instrument through a threetier partnership by including a new contracting party. The proposed financial design allows the contracting parties to benefit from the risk-sharing mechanism through an option contract, giving them the incentive to share the risk of the project and handle agency problems. More precisely, they suggested a new generalized financial scheme that allows the contracting parties to deal with cash-flow default and to manage risk through a sharing mechanism. Considered as a risk moderator, this new party can absorb the underlying risk of default and adjust the annual revenue to a predetermined annual cost. The authors considered a dynamic capital structure methodology for the valuation of the PLS option that allows for an annual adjustment of the project's revenue and recalculates the entitlements pertaining to the contracting parties. Furthermore, they opted for the Monte Carlo simulation to evaluate the project when the construction cost is deterministic and the streams of expected cash flows are stochastic. Interestingly, the simulation results showed that the dynamic adjustment of the capital structure simultaneously endorses a recursive profit-and-loss sharing and a dynamic risk-hedging approach. This evidence implies that "the immunization against premature default through the involvement of the risk moderator to absorb any potential loss, which is indicative of an incentive factor for the project's survival and business continuity" (Mansour et al., 2015, pp. 21-22).

Al-Suwailem (2005, pp. 157-173) examined the optimal sharing contract by comparing PLS contracts to standard debt $(r i b \bar{a})$ contracts under symmetric and asymmetric information. It was found that when bankruptcy costs are positive and the expected marginal gain is not less than the marginal loss, aggregate expected profits from sharing exceed those of debt under both symmetric and asymmetric information. This result holds despite that the effort level is the same in both contracts. Moreover, for a certain range of the opportunity cost, both the financier and the agent are better off signing a sharing contract instead of debt.

The model is extended to include endogenous cost of bankruptcy and endogenous probability of success. These extensions confirm the above results regarding 
expected profits. Level of effort in debt, however, may be below or in excess of the efficient level, resulting in sub-optimal payoff. The model is applied to different forms of sharing, including that of a manager-partner as well as partnerships or sharikä̈ al-inān. Optimal sharing ratios in each case are derived. Finally, the interaction between agents has been presented in a game-theoretic framework. As game theory shows below, optimality cannot be reached if there is an incentive for each party to exploit the other. Thus, debt may emerge as a response to non-cooperative behavior, unless there is a mechanism to reward cooperation and punish exploitation and defection. Based on the forgoing insights, figure 4 defines the game-theoretic framework.

Figure (4) Cooperative Game Mechanism

Entrepreneur

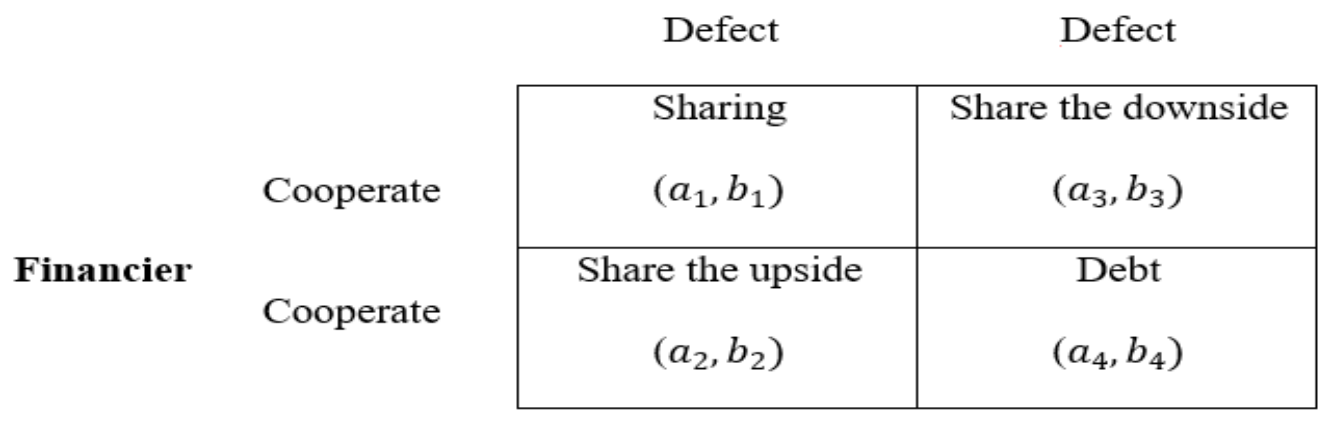

Source: al-Suwailem (2005, p. 171).

In order to settle the game strategy, the study considered an environment where there is no prior commitment through binding contracts. Rather, selection of the type of compensation evolves endogenously. Since there is no commitment in this setting, there are no bankruptcy costs. Before starting the game, the financier advances capital to the entrepreneur, where the latter offers a form of security or collateral to the financier. By the end of the period, the entrepreneur is able separately to observe the state of the world and announces the return. Afterwards, the return becomes visible to both parties. To simplify, the author assumed that the entrepreneur can announce either gains or losses and no intermediate value may be announced (al-Suwailem, 2005, p. 170).

Based on the study of Hirshleifer and Riley (1992), the Prisoner's Dilemma game is defined as a game in which payoffs of the first row players are arranged as $a_{2}>a_{1}>a_{4}>a_{3}$. For the second player it is organized as $b_{3}>b_{1}>b_{4}>b_{2}$. After calculating the different payoffs, the author compared them in order to test whether his framework is convenient with the definition above. Afterwards, he summarized the possible outcomes as illustrated in the table below, where $\left\langle a_{i}\right.$ » represents the financier's payoff and $\left\langle b_{i}\right\rangle$ represents that of the entrepreneur. In result, the entrepreneur and the financier might each be honest or dishonest. An honest financier would respond with cooperation, thus sharing gain in case of success and assuming losses in case of failure. Thus, the outcome (Cooperate, Cooperate) corresponds to a sharing contract. Nevertheless, a dishonest entrepreneur announces losses even in case of success. If the financier is honest and cooperates, the outcome (Cooperate, Defect) results in the entrepreneur exploiting the financier because he enjoys the entire gains in case of success but lets the financier assume losses in case of failure. Consequently, the financier shares only losses. However, if the financier suspects that the entrepreneur is dishonest, he would refuse to cooperate and thus decides to recover announced losses plus interest from the provided security. This results in the outcome (Defect, Defect) corresponding to the standard debt contract (alSuwailem, 2005, pp. 170-171). 
In the same context, when the financier is not honest, he will refuse to cooperate even if the entrepreneur honestly announces losses. The outcome thus is (Defect, Cooperate), whereby the financier exploits the entrepreneur. In this case, the financier shares gains but not the losses. In response, the entrepreneur would refuse to cooperate in the next round. In sum, the author asserts that presenting the choice between debts and sharing using the Prisoner's Dilemma framework provides valuable insights into the problem. It shows that from a normative point of view, sharing pareto-dominates debt as both parties are better off switching from $\left(a_{4}, a_{4}\right)$ to $\left(a_{1}, b_{1}\right)$. Nevertheless, on the positive side, the author argued that debt prevails in the presence of suspicion and lack of honesty; factors frequently cited in reality for avoiding sharing financing. "Debt therefore emerges out of selecting dominant strategies, even though it is Pareto-inferior to sharing" (al-Suwailem, 2005, p. 173). Admitting that Islamic scholars have different perspectives regarding Islamic financing contracts, the forgoing studies came out with relevant insights regarding the feasibility of Islamic financing modes. Nevertheless, it has been noticed that further justifications must be considered regarding the gaps in the Islamic studies that we shall discuss in the next subsection.

\subsection{Gaps in the Islamic Literature}

Based on these studies in Islamic finance, it has been noticed that there is a lack of insight regarding the selection of the optimal contract that aligns agents' interests and maximizes the value of the firm among equity-based contracts and debt-based contracts. More precisely, several papers examined equity financing either from the entrepreneur point of view or from the principal's perspective. Therefore, this paper proposes two approaches that consider the interests of the principal and the agent in order to determine the optimality of the PLS arrangement when moral hazard and market frictions occur. Admitting that alSuwailem (1998) assumed that venture capital might be an alternative model of mushārakah, further empirical evidences are needed with the aim to determine whether venture capital may allow agents to handle conflicts of interest and avoid bankruptcy.

Concerning debt-based instruments, the literature justified that the excessive use of muräbahah instead of $i j a \bar{r} r a h$ is most likely attributed to legal issues related to the ownership of the asset. However, a lot of concession and changes have been made to allow the bank to have ownership of the asset in murābahah for a momentary period, whereas in ijärah, the bank owns the asset until the end of the contract. Therefore, many complications may occur when ijärah financing is used. Based on the forgoing insights, it is recommended also to examine ijārah and murābahah financings from the financial perspective in order to come out with financial and economic arguments supporting IFSB financial statements in this context.

To do so, this paper proposes two alternative approaches where the first one aims at assessing the optimal financing contract that maximizes the value of the firm subject to the interests of the principal and the agent in imperfect markets. The second approach considers an adverse selection analysis to deal with asymmetric information problem in order to analyze the principal's subjective perception of the default risk and determine the less risky financing instrument for the principal. To this extent, the aforementioned approaches are discussed in the next section.

\section{Alternative Approaches 5.1 Financial Contracting Enforceability Approach}

The notion of enforceability is one important process in financial contracting. It is defined according to the literature as the ability of each part to repudiate the contract for a given reason. Several papers dealt with this issue to study the risk of repudiation in case of limited liability or to find out the optimal lending contract through the financial contracting enforceability theory (Atkeson, 1991; Kehoe \& Levine, 1993; Quintin, 2008; Marcet \& Marimon, 1992; Cooley, Marimon, \& Quadrini, 2004; Albuquerque \& Hopenhayn, 2004).

Cooley et al. (2004, pp. 824-825) mention that the optimal contract must maximize the value of the firm subject to two constraints, which are the enforcement constraint for the agent and the participation constraint for the principal. The first constraint shows that the agent (the firm) may accept to enforce the contract when the expected profit generated exceeds the default value. This default value is an endogenous function depending on the capital invested and the industrial shocks affecting the profit of the firm. The second constraint implies that the expected profit 
share for the principal (the banker) must be greater or equal to the set-up investment. Otherwise, the contract will not be executed. Based on the financial contracting enforceability approach proposed by them (among others), we become able to determine the contract that maximizes the value of the firm and aligns agent's interests in the case of imperfect markets.

Comparing with the previous studies in Islamic and conventional finance, this approach allows us to determine the optimality of equity and debt financings based on the interests of the principal and the agent. In addition, it enables us to assess the level of market frictions that the principal and the agent may bear if they want to maximize their profit. In sum, this method allows us to deal with contractual arrangements from a new angle with the aim to come out with relevant insights regarding conflict of interest mitigation in imperfect markets.

\subsection{Adverse Selection Analysis}

Adverse selection problem arises before the contract is signed because the bank has less information on the project and the firm itself. When the bank has the same information as the firm, adverse selection analysis becomes unnecessary. This, however, is not the case because, in reality, the information gap between the lender and the borrower increases when moral hazard occurs. While adverse selection problems come from the asymmetric information factor and moral hazard, several studies dealt with this area in order to provide further explanations. Among others, Arrow (1971) examined the theory of risk aversion and the role of securities in the optimal allocation of risk-bearing. The author adopted this theory to explain and understand observable economic behavior and institutions, and to derive the performance characteristics of non-observed economies by a reinterpretation of the arguments and equations of a received theory, or by a mathematical formalism. To this extent, he gave precision to the concept of risk aversion for the purpose of explaining observed aspect of investment, insurance, risk sharing, and also liquidity demand behavior.

Regarding the importance of the adverse selection issue, Holmstrom (1982. p. 324) showed that orthodox economic theory did not provide sufficient details in terms of understanding the principal-agent problem in contractual arrangements. This is because traditional theory pays little or no attention to the role of information. Therefore, Arrow (1974) paid more attention to the questions linked to the central agent's incentives because it dictates the structure of organizations and identifies the limits of its performance potential. Generally, the members of an organization may provide two types of services. They supply inputs for production and process information for decision-making. Hence,

along with this dichotomy goes a taxonomy for incentive problems. Moral hazard refers to the problem of inducing agents to supply proper amounts of productive inputs when their actions cannot be observed and contracted for directly. Adverse selection refers to a situation where actions can be observed, but it cannot be verified whether the action was the correct one, given the agent's contingency, which he privately observes. (Holmstrom, 1982, p. 324).

By pursuing the aforementioned idea, the adverse selection issue has been examined in different areas such as the financial markets (see e.g., Chang \& Wang, 2015; Kawai, 2015) and contractual arrangements (see e.g., Opitz \& Hoffmann, 2014; Braun, Jenkinson, \& Schemmerl, 2018), while it has a major role in the investment decision.

Based on the foregoing studies, it is obviously clear that the adverse selection issue has a relevant impact on the financing decision of economic agents in the market as well as in contractual arrangements. Dealing with financial contracts, the literature asserts that the principal (financier) and the agent (entrepreneur) are exposed to the adverse selection problem due to the existence of moral hazard and asymmetric information, implying that bankruptcy is more likely to occur if one party does not honor its obligations. Consequently, a former bankruptcy procedure must be established in order to protect the interest of creditors. However, the literature has shown that this procedure is very complicated in practice, implying that another alternative should be implemented so as to avoid default risk and bankruptcy.

Ahmed (2002, pp. 45-49) came up with a theoretical framework for PLS financing contracts based on the study by Gale and Hellwing (1985) with the aim of determining the incentive-compatible contracts. While banks do not mostly have the incentive to enforce PLS contracts, he proposed several incentives 
to bankers and entrepreneurs to proceed with this financing contract. More precisely, the author showed that the specification of the profit share, the adverse selection analysis, the auditing rule, and the reward/punishment rules are fundamental to build a strong partnership in imperfect markets.

Furthermore, Ahmed (2002, pp. 46-47) proposed a repayment function defining the transfer promised to the principal (the bank) by the agent (the firm) as a function of the profit in case of equity financing. In particular, the repayment function depicts the ratio at which profit will be shared between the firm and the bank. It is composed by the risk-free rate, the profit generated by the project, market frictions, the safety index, the audit parameter, and the capital invested. Although the expected profit generated and the riskfree rate can be estimated or calculated, the determination of the safety index remains arbitrary based on the quality of the information collected and the banker's subjective assessment of these inputs. In practice, banks undertake a given project when the riskadjusted expected rate of return exceeds the return from the risk-free return. Whilst the first component of the risk-adjusted expected rate of return is composed of a random parameters defining the safety index and the expected profit generated, the second component represents the return from the risk-free return, which is the conventional benchmark.

Based on the aforementioned insight, a modified version of Ahmed's model can be proposed in order to calculate a safety index defining the principal's subjective perception of the risk of default in case of debt financing. Admitting that the audit cost can be shared equally in case of equity financing, Ahmed (2002) asserted that "since a profit-sharing arrangement is a partnership, we assume both parties share ex ante the auditing cost equally" (p. 46). Besides the assessment of the principal risk tolerance, this analysis enables us to determine the level of market frictions the principal may bear and the level of audit that agents may consider in case of equity and debt financings.

\section{Perspectives of the Financial Contracting Theory}

Both the conventional literature and the Islamic literature have dealt with the financial contracting theory in order to mitigate conflicts of interest on the one hand, and determine the optimal financing mode for economic agents on the other hand. The conventional literature was the first to examine the contractual arrangements, the theory of the firm, and the agency theory. It came out with relevant insights regarding human cooperation when moral hazard and market frictions occur, whereas it ignored the internal organization of the firm. This evidence encouraged the new generation of economists to come up with a new theory, which is the incomplete contract theory (see e.g., Hart, 1995; Aghion \& Bolton, 1997). The theory puts stress on bargaining power in the process of negotiation and renegotiation in order to align agents' interests in case of partnership agreement.

More precisely, the theory adopted some insights from the theory of the firm, the agency theory, and the theory of ownership in order to build a new framework that considers the internal organization of the firm. At the end of the day, it succeeded to mitigate conflicts of interest among agents. The incomplete contract theory has been developed based on several hypotheses assuming three important conditions: (i) The principal is risk-neutral; (ii) There is only one principal and one agent; and (iii) The agents have symmetric information ex-ante.

Based on these hypotheses, the approach implies that since the principal is wealthy, the risk component will not be affecting in his model. However, riskneutrality constitutes a relevant issue in this regard when it comes to the principal with different risk expectations, particularly in the case of intermediated funds as we cannot simply assume that bankers are risk-neutral (see Arrow, 1971, for examination of the theory of risk bearing in the presence of uncertainty). Also, the assumption that agents do not face asymmetric information problem ex-ante is a rather strong assumption to make (see Ross, 1973, for the examination of contractual arrangement in the presence of asymmetric information). Accordingly, it would be hard to admit the first and the third hypotheses of the incomplete contract theory in our study, as in real practice bankers cannot be risk neutral. In addition, information asymmetry represents the main determinant of any investment decision (for a theoretical background on information asymmetry, see Chichti \& Mansour, 2010a, 2010b, 2012; Mansour, 2014). 
The examination of the incentives, moral hazard, and asymmetric information issues have not been definitely resolved and remain an interesting research area. From the conventional perspective, the financial contracting enforceability approach can be a relevant method to examine contractual arrangements. By considering the interests of the principal and the agent as constraints in the general framework, it becomes interesting to assess the optimal contract for agents when market frictions occur. Comparing with the incomplete contract theory, this approach does not consider the symmetric information ex-ante and the principal risk neutrality. Therefore, the determination of the level of market frictions that agents may bear in the case of equity or debt financings represents a relevant indicator for bankers and financiers in order to handle conflicts of interest among agents.

Similarly, the adverse selection analysis allows us to assess the principal subjective perception of the risk of default in case of equity and debt financing. More precisely, it enables us to calculate the principal's risk tolerance depending on the profit generated, the capital invested, and market frictions in particular. In addition, this approach may provide relevant evidence regarding the level of audit that the principal may consider to compensate the variation of market frictions and mitigate bankruptcy. This simple framework can be a relevant tool for bankers to determine the risk that the principal is expecting from a given project.

Dealing with the Islamic studies in financial contracting theory, several authors such as Maghrebi and Mirakhor (2015), Nabi (2013), al-Suwailem (2005), and Ahmed (2002) considered the allocation of decision and right to deal with PLS contracts, which constitute a challenge for Islamic financial institutions. The literature is divided into two streams where the first one encourages the adoption of PLS contracts as they have a positive impact on financial inclusion and mitigate income inequality, while the second one criticizes equities due to moral hazard issues without providing significant quantitative evidences. Furthermore, the recent literature has focused on PLS contracts and has not yielded sufficient explanation regarding the excessive use of muräbahah instead of ijarrah on the one hand, and the substitution of mushärakah by venture capital on the other hand.

\section{Conclusion and Recommendations for Future Research}

In this paper, financial contracting theory has been examined from the conventional and the Islamic perspectives due to the impact the principal-agent problem has on the financing decision and the growth of the firm. The incomplete contract theory came out with relevant insights regarding conflicts of interest mitigation between agents. However, some hypotheses linked to symmetric information ex-ante, and the principal risk neutrality have been criticized because it is hard to admit that bankers and entrepreneurs are risk neutral.

Therefore, this paper proposes two alternative approaches namely the financial contracting approach and the adverse selection analysis. Compared to the existing studies in the field, the first approach considers the interests of the principal and the agent for the determination of the optimal contract. Furthermore, it allows us to assess the level of market frictions that agents may bear if they want to maximize their profit. The second approach assesses the principal's risk tolerance when financing is obtained through equities or debts. More precisely, it allows us to identify the principal's perception of the risk of default for equities and debt. In addition, the level of market frictions that the principal may bear and the level of audit that he may undertake to mitigate bankruptcy can also be determined in order to get a clear idea about the financing decision.

Regarding the Islamic studies, several papers examined PLS contracts either from the principal's point of view or from the agent's perspective. Although venture capital has been proposed as a potential model of mushärakah, additional evidences are needed to support this proposition. By putting stress on conflicts of interest between agents and the adverse selection problem, relevant arguments can be provided regarding the most attractive contract for the agents among venture capital and mushārakah.

This paper also sheds some light on some relevant topics that we may examine in contractual arrangements with respect to the Islamic perspective. By assuming that venture capital can be a potential model of musharakah, the aforementioned approaches may provide theoretical evidences regarding conflicts of interest mitigation and adverse selection issues (for 
future research directions in case of venture capital financing, see Devigne, Manigart, Vanacker, \& Mulier, 2018).

In the same context, this paper discusses the necessity to provide further evidences regarding the excessive use of murābahah instead of ijārah in Islamic finance. The preference of muräbahah is attributed to the legal challenges related to the ownership of the asset when ijärah financing is used. Nevertheless, additional financial explanations are needed in order to explain the preference of murābahah instead of ijārah by Islamic financial institutions. The lack of insights regarding the excessive use of muräbahah instead of ijärah can motivate us to consider the financial contracting enforceability approach and the adverse selection analysis in order to come out with financial evidences supporting IFSB statements.

This paper also highlights that the crowd-funding agreement can be an interesting area of study, as the number of crowd-funded projects has increased significantly during the last ten years especially by small firms and start-ups. For instance, it would be interest-

\section{References}

Aghion, P., \& Bolton, P. (1997). A Theory of TrickleDown Growth and Development. The Review of Economic Studies, 64(2), 151-172.

Ahmed, H. (2002). Incentive-compatible profit-sharing contracts: a theoretical treatment. In M. Iqbal \& D. T. Llewellyn (Eds.), Islamic Banking and Finance: New Perspective on Profit-Sharing and Risk (pp. 40-54). Cheltenham, UK: Edward Elgar Publishing Limited.

Akerlof, G.A. (1970). The Market for "Lemons": Quality Uncertainty and the Market Mechanism. The Quarterly Journal of Economics, 84(3), 488-500.

Albuquerque, R.A., \& Hopenhayn, H. A. (2004). Optimal Lending Contracts and Firm Dynamics. The Review of Economic Studies, 71(2), 285-315.

Arrow, K. J. (1971). Essays in the Theory of Risk Bearing. Chicago, USA: Markham Publishing Company.

Arrow, K. J. (1974). The Limits of Organization. New York, USA: W.W. Norton \& Company.

Atkeson, A. (1991). International Lending with Moral Hazard and Risk of Repudiation. Econometrica, 59(4), 1069-1089. ing to shed some light on this contract in order to find out the motivations behind forming this kind of project explain. Similarly, the motivation behind the use of crowd funding by economic agents from the Islamic perspective could also be an interesting area of research. Besides its main function of money provider, current research lacks a deep knowledge on crowd-funding related areas, such as inter alia, for the purpose of pre-sale marketing and market research (for the examination of crowd-funding of small entrepreneurial ventures, see Schwienbacher \& Larralde, 2012; see also Ordanini, Miceli, Pizzetti, \& Parasuraman, 2011, for an analysis of the crowdfunding phenomenon). Similarly, future researches may highlight the risk and uncertainties related to this financing tool in order to set up the appropriate risk management procedure for this contract (Gierczak, Bretschneider, \& Leimeister, 2014; Mollick, 2014). Hence, the financial contracting enforceability approach and the adverse selection analysis that we have explained in this paper can be adopted to examine crowd funding from the principal-agent overview in imperfect markets.

Braun, R., Jenkinson, T., \& Schemmerl, C. (2018). Adverse Selection and the Performance of Private Equity Co-Investments (Working paper). Retrieved from: https://papers.ssrn.com/sol3/papers.cfm? abstract_id $=2871458$

Bedoui, H.E., \& Mansour, W. (2015). Performance and Maqasid al-Shari'ah's Pentagon-Shaped Ethical Measurement. Science and Engineering Ethics, 21(3), 555576.

Chang, S.S., \& Wang, F. A. (2015). Adverse Selection and the Presence of Informed Trading. Journal of Empirical Finance, 33, 19-33.

Chichti, J.E., \& Mansour, W. (2010a). Is the investmentcash flow sensitivity still useful to gauge financing constraints? International Journal of Economic Policy in Emerging Economies, 3(1), 71-84.

Chichti, J.E., \& Mansour, W. (2010b). Investment, Marginal Q, and Net Worth: Evidence from Europe. The IUP Journal of Applied Economics, 9(3), 5-50.

Chichti, J.E., \& Mansour, W. (2012). Investment lumpiness and the role of net worth: evidence from Europe. International Journal of Behavioural Accounting and Finance, 3(3/4), 145-162. 
Coase, R. H. (1937). The Nature of the Firm. Economica, 4(16), 386-405.

Cooley, T., Marimon, R., \& Quadrini, V. (2004). Aggregate Consequences of Limited Contract Enforceability. Journal of Political Economy, 112(4), 817-847.

Dar, H.A., \& Presley, J.R. (2000). Lack of Profit Loss Sharing in Islamic Banking: Management and Control Imbalances. International Journal of Islamic Financial Services, 2(2), 3-18.

Devigne, D., Manigart, S., Vanacker, T., \& Mulier, K. (2018). Venture capital Internationalization: Synthesis and Future Research Directions. Journal of Economic Surveys, 32(5), 1414-1445.

Ebrahim, M.S., \& Sheikh, M. (2016). Debt Instruments in Islamic Finance: A Critique. Arab Law Quarterly, 30(2), 185-198.

Ernawati, E. (2016). Risk of profit loss sharing financing: The case of Indonesia. Al-Iqtishad: Jurnal Ilmu Ekonomi Syariah (Journal of Islamic Economics), 8(1), 101-116.

Farooq, M.O. (2007). Partnership, Equity-Financing and Islamic Finance: Whither Profit-Loss Sharing? Review of Islamic Economics, 11(Special Issue), 67-88.

Gale, D., \& Hellwing, M. (1985). Incentive-Compatible Debt Contracts: The One-Period Problem. The Review of Economic Studies, 52(4), 647-663.

Gierczak, M.M., Bretschneider, U., \& Leimeister, J.M. (2014). Is all that Glitters Gold? Exploring The Effects of Perceived Risk on Backing Behavior in Reward-based Crowdfunding. Paper presented at the International Conference on Information Systems (ICIS), Auckland, New Zealand. Retrieved from: https:/www.alexandria.unisg.ch/235238/1/JML_517.pdf

Halonen-Akatwijuka, M., \& Hart, O. (2015). Continuing Contracts (Bristol Economics Discussion Paper No. $15 / 665$, University of Bristol, UK). Retrieved from: http://www.bristol.ac.uk/efm/media/workingpapers/wo rking_papers/pdffiles/dp15665.pdf

Hart, O. (1989). An Economist's Perspective on the Theory of the Firm. Columbia Law Review, 89(7), 17571774.

Hart, O. (1995). Firms, Contracts and Financial Structure. Oxford, UK: Clarendon Press.

Hart, O. (2003). Incomplete Contracts and Public Ownership: Remarks and an Application to Public-Private partnerships. The Economic Journal, 113(486), 69-76.

Hart, O. (2017). Incomplete Contracts and Control. American Economic Review, 107(7), 1731-1752.
Hart, O., \& Moore, J. (1994). A Theory of Debt Based on the Inalienability of Human Capital. The Quarterly Journal of Economics, 109(4), 841-879.

Hasan, Z. (1985). Determination of Profit and Loss Sharing Ratios in Interest-Free Business Finance. Journal of Research in Islamic Economics, 3(1), 13-29.

Hirshleifer, J., \& Riley, J.G. (1992). The Analytics of Uncertainty and Information. Cambridge, UK: Cambridge University Press.

Holmstrom, B. (1982). Moral Hazard in Teams. The Bell Journal of Economics, 13(2), 324-340.

Jensen, M.C., \& Meckling, W.H. (1976). Theory of the Firm: Managerial Behavior, Agency Costs and Ownership Structure. Journal of Financial Economics, 3(4), 305-360.

Kawai, K. (2015). Reputation for Quality and Adverse Selection. European Economic Review, 76, 47-59.

Kehoe, T.J., \& Levine, D.K. (1993). Debt-Constrained Asset Markets. The Review of Economic Studies, 60(4), 865-888.

Khaled, S.A., \& Khandker, A.W. (2015). Profit-Loss Sharing Contract Formation Under Zero Interest Financial System. Journal of King Abdulaziz University: Islamic Economics, 28(2), 75-107.

Khan, M.S., \& Mirakhor A. (Eds.). (1987). Theoretical Studies in Islamic Banking and Finance. Houston, USA: The Institute for Research and Islamic Studies.

Lone, F.A., \& Quadir, A. (2017). Incentive Structure of Financing a Project: An Islamic Finance Approach. International Journal of Economics and Financial Issues, 7(1), 87-91.

Marcet, A., \& Marimon, R. (1992). Communication, Commitment, and Growth. Journal of Economic Theo$r y, 58(2)$, pp 219-249.

Maghrebi, N., \& Mirakhor, A. (2015). Risk Sharing and Shared Prosperity in Islamic Finance. Islamic Economic Studies, 23(2), 85-115.

Majdoub, J., \& Mansour, W. (2014). Islamic equity market integration and volatility spillover between emerging and US stock markets. The North American Journal of Economics and Finance, 29, 452-470.

Majdoub, J., Mansour, W., \& Jouini. J. (2016). Market integration between conventional and Islamic stock prices. The North American Journal of Economics and Finance, 37, 436-457.

Majdoub, J., Mansour, W., \& Arrak, I. (2018). Volatility Spillover among Equity Indices and Crude Oil Prices: Evidence from Islamic Markets. Journal of King Abdulaziz University: Islamic Economics, 31(1), 27-45. 
Mansour, W. (2014). Information asymmetry and financing constraints in GCC. The Journal of Economic Asymmetries, 11, 19-29.

Mansour, W., Ben Abdelhamid, M., \& Heshmati, A. (2015). Recursive Profit and Loss Sharing. Journal of Risk, 17(6), 21-50.

Mirakhor, A. (1987). Short-term Assets Concentration in Islamic Banks. In M. S. Khan \& A. Mirakhor (Eds.), Theoretical Studies in Islamic Banking and Finance (pp. 185-200). Houston, USA: The Institute for Research and Islamic Studies.

Muda, R., \& Ismail, A. G. (2010). Profit-Loss Sharing and Value Creation in Islamic Banks. Journal of Business and Policy Research, 5(2), 262-281.

Mollick, E. (2014). The dynamics of crowd-funding: An exploratory study. Journal of Business Venturing, 29(1), 1-16.

Nabi, S. (2012). A Theory of Profit Sharing, Income Inequality and Capital Accumulation (IRTI Working Paper No. 1433-03). Retrieved from: https://mpra.ub.unimuenchen.de/49830/1/MPRA_paper_49830.pdf

Nabi, S. (2013). Access to Finance and Investment: Does Profit Sharing Dominate Debt? [Profit Sharing and Debt Contracts in Presence of Moral Hazard] (IRTI Working Paper No. 1434-02). Retrieved from: https://mpra.ub.unimuenchen.de/49815/1/MPRA_paper_49815.pdf

Opitz, C., \& Hofmann, K. H. (2014). Adverse Selection and Moral Hazard in Equity Partnerships: Evidence from Hollywood's Slate Financing Agreements. Journal of Economics and management Strategy, 23(4), 811-838.

Ordanini, A., Miceli, L., Pizzetti, M., \& Parasuraman, A. (2011). Crowd-funding: Transforming customers into investors through innovative service platforms. Journal of Service Management, 22(4), 443-470.

Quintin, E. (2008). Limited Enforcement and the Organization of Production. Journal of Macroeconomics, 30(3), 1222-1245.

Ross, S. A. (1973). The Economic Theory of Agency: The Principal's Problem. The American Economic Review, 63(2), 134-139.

Sarker, M.A.A. (1999). Islamic Business Contracts, Agency Problem and the Theory of the Islamic firm. International Journal of Islamic Financial Services, 1(2), 12-28.
Sapuan, N.M. (2016). An Evolution of Mudarabah Contract: A Viewpoint From Classical and Contemporary Islamic Scholars. Procedia Economics and Finance, 35, 349-358.

Schwienbacher, A., \& Larralde, B. (2012). Crowdfunding of small entrepreneurial ventures. In D. Cumming (Ed.), The Oxford handbook of entrepreneurial finance (pp. 369-391). Oxford, UK: Oxford University Press.

Siddiqui, A. (2008). Financial contracts, risk and performance of Islamic banking. Managerial Finance, 34(10), 680-694.

Siddiqi, N. (1988). Islamic Banking: Theory and Practice. In M. Ariff (Ed.), Islamic Banking in Southeast Asia: Islam and the Economic Development of Southeast Asia (pp. 34-66). Singapore: Institute of Southeast Asian Studies.

Smith, A. (1776). An Inquiry into the Nature and Causes of the Wealth of Nations. London, UK: William Strahan and Thomas Cadell.

State Bank of Pakistan, Islamic Banking Department. (2018). Islamic Banking Bulletin: March 2018. Retrieved from: http://www.sbp.org.pk/ibd/bulletin/2018/Mar.pdf

al-Suwailem, S. (2005). Optimal Sharing Contracts: Properties and Evolution. In M. Iqbal \& T. Khan (Eds.), Financial Engineering and Islamic Contracts (pp. 146196). Basingstoke, UK: Palgrave Macmillan.

al-Suwailem, S. (1998). Venture Capital: A Potential Model of Musharakah. Journal of King Abdulaziz University: Islamic Economics, 10, 3-20.

Tag el-Din, S. I. (1991). Risk-aversion, Moral Hazards and Financial Islamization Policy. Review of Islamic Economics, 1(1), 49-66.

Tirole, J. (1999). Incomplete Contracts: Where Do We Stand? Econometrica, 67(4), 741-781.

Warne, K.F. (1988). Essays on the Venture Capital Market (Unpublished Doctoral Dissertation). Yale University, New Haven, Connecticut, USA.

Williamson, O.E. (1979). Transaction-Cost Economics: The Governance of Contractual Relations. The Journal of Law \& Economics, 22(2), 233-261.

World Bank, \& Islamic Development Bank Group. (2016). Global Report on Islamic Finance: Islamic Finance - A Catalyst for Shared Prosperity. Washington, DC: World Bank. 
Hechem Ajmi is currently a PhD candidate at the IIUM Institute of Islamic Banking and Finance, International Islamic University Malaysia (IIUM). He graduated from "L'ecole Superieur de Commerce de Tunis" to earn his Master and bachelor degrees in finance. His research interests include Islamic financial contracting, the incomplete contract theory, corporate finance, market finance and behavioral finance.

E-mail: hechemajmi@gmail.com

Hassanuddeen Aziz is currently Professor at the Faculty of Economics and Management Sciences, International Islamic University Malaysia (IIUM). He teaches Islamic capital market, Money, Banking and Capital markets, Portfolio Management and Managerial Finance. His research interests include Islamic banking and finance and behavioral finance. He has published extensively in several academic journals in his areas of research interest. He earned his $\mathrm{PhD}$ in Economics from the University of Illinois and his Masters and Bachelor degrees from the University of Rochester and University Malaya (UM), respectively.

E-mail: hassanuddeen@gmail.com

Salina Kassim is currently Associate Professor at the IIUM Institute of Islamic Banking and Finance, International Islamic University Malaysia (IIUM). Prior to becoming an academician, she has several years of working experience in a commercial bank in Malaysia. She teaches Money and Banking, and Islamic Banking and Finance at the under-graduate level, and Islamic Financial Systems, Financial Economics and Contemporary Issues in Islamic Finance at the graduate level. Her research interests include Islamic banking and finance, and monetary/financial economics. She has published extensively in refereed academic journals in her areas of research interest. She also sits on the editorial boards of several reputable international journals. She earned her PhD in Monetary Economics in 2006 from the IIUM and her Masters and Bachelor degrees from the USA in 1992 and 1994, respectively.

E-mail: ksalina@iiium.edu.my

Walid Mansour is an Advisor at the Financial Sector Development Department of the Saudi Arabian Monetary Authority (SAMA). He has research and consultancy experience in the field of Islamic finance, investments, and Islamic financial products development. He has published several articles in international journals. He holds a $\mathrm{PhD}$ in finance and a post-doctoral diploma from Kansas University.

E-mail: walid.mansour@fulbrightmail.org 


\title{
استعراض أدبيات نظرية التعاقد المالي من المنظور الإسلامي والتقليدي:

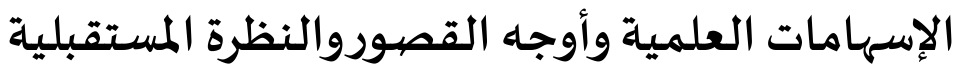

\author{
هاشم عجمي وسالينة قاسم \\ معهل المصرفية والتمويل الإسلامي، الجامعة الإسلامية العالمية بماليزيا \\ حسان الدين عزيز \\ كلية الاقتصاد والعلوم الإدارية، الجامعة الإسلامية العالمية بماليزيا \\ وليد منصور \\ مؤسسة النقل العربي السعودي، المملكة العببية السعودية منهور
}

المستخلص: يناقش البحث نظرية التعاقد المالي من المنظور الإسلامي والتقليدي، حيث يقدم في

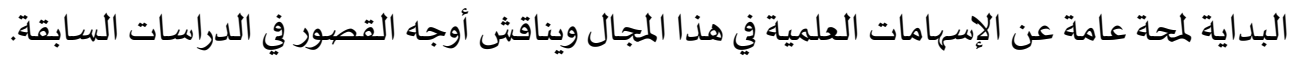

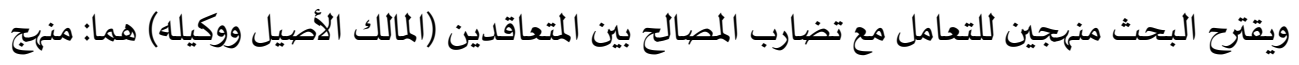

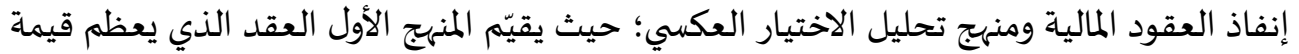

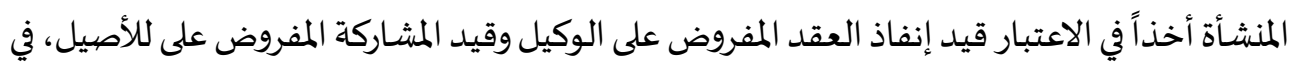

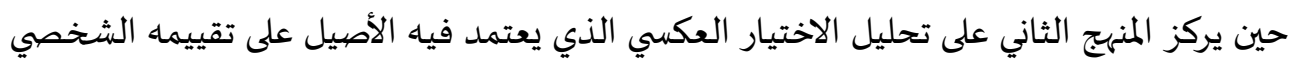

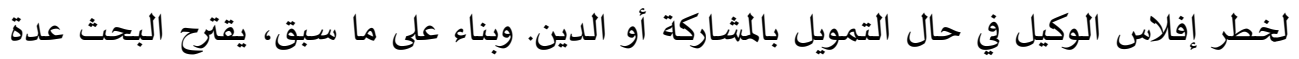

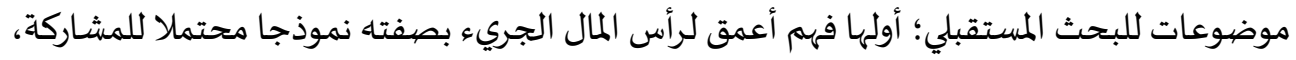

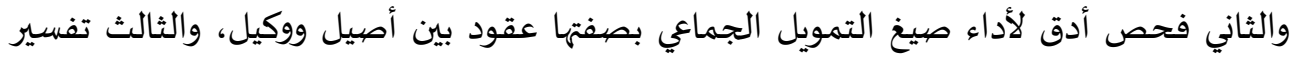

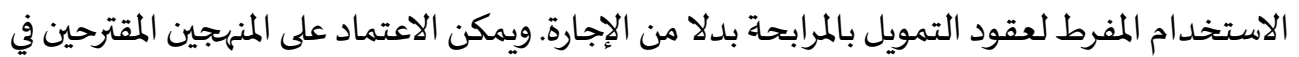

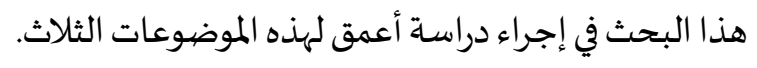

الكلمات الدَّالة: تضارب المصالح، العقد الأمثل، الاختيار العكسي، العقود القائمة على المشاركة،

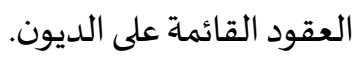

تصنيف G32, G33, G23, G24 :JEL

تصنيف Q1, L3, T3 :KAUJIE 